\title{
DISAIN PISAU BOWL CUTTER UNTUK PEMBUATAN NUGGET IKAN
}

\section{Bowl Cutter Blade Design for Fish Nugget Production}

\author{
Tri Nugroho Widianto*, Toni Dwi Novianto dan Naila Zulfia \\ Loka Penelitian dan Pengembangan Mekanisasi Pengolahan Hasil Perikanan, JI Imogiri Barat Km 11,5 \\ Bantul, DI Yogyakarta, Indonesia \\ * Korespondensi penulis: trinugrohowidianto@yahoo.com \\ Diterima :28 Februari 2016 ; Disetujui : 30 Mei 2016
}

\begin{abstract}
ABSTRAK
Penelitian disain pisau bowl cutter untuk pembuatan nugget ikan telah dilakukan. Penelitian ini bertujuan untuk mendapatkan bentuk dan jumlah pisau bowl cutter yang optimal untuk pembuatan nugget ikan. Penelitian dilakukan melalui beberapa tahapan yaitu penentuan kriteria disain, penentuan konsep disain, dan pembuatan alat dan uji kinerja. Pisau bowl cutter dibentuk dalam 3 buah disain yaitu tiga pisau lurus, tiga pisau melengkung dan enam pisau melengkung. Material pisau menggunakan stainless steel 304. Uji kinerja dilakukan dengan membuat adonan nugget ikan menggunakan bowl cutter selama 8, 12 dan 16 menit. Untuk mengetahui kualitas nugget ikan, parameter mutu yang diamati meliputi kadar air, tekstur, susut masak, water holding capacity (WHC) dan uji organoleptik. Biaya operasional listrik diketahui dengan mengukur konsumsi energi yang digunakan oleh motor listrik bowl cutter. Hasil penelitian menunjukkan bahwa disain bowl cutter terbaik terdiri dari tiga pisau melengkung dengan lama pengadonan 8 menit yang menghasilkan nugget dengan kadar air 54,2\%, tekstur sebesar 12,6 N, susut masak $16,7 \%$, WHC 32,9\%, nilai organoleptik lebih dari 7 dan biaya operasional listrik sebesar Rp. $2.700,-/ 100 \mathrm{~kg}$ adonan.
\end{abstract}

KATA KUNCl: bowl cutter, pisau, nugget ikan, disain

\begin{abstract}
Research on bowl cutter blade design for fish nugget production had been conducted. This research aimed to obtain best blade shape and number of bowl cutter blade for fish nugget production. This study was carried out through several steps, i.e. defining the design criteria, defining conceptual design, blades manufacturing, and performance testing. Three bowl cutter blade designs were created, i.e. three straight blades, three curve blades, and six curve blades. The blade material used was 304-stainless steel. Performance test was carried out using the bowl cutter to make the dough for fish nuggets for 8, 12 and 16 minutes of kneading time. To determine the quality of fish nuggets, the following parameters were observed: moisture content, texture, cooking loss, water holding capacity (WHC) and sensory characteristics. The electricity operating cost was determined by measuring the energy comsumption used by the motor of bowl cutter. The results showed that the best design of bowl cutter blade was consisting of the three curve blades with kneading time of 8 minutes, producing nuggets with moisture content of $54.2 \%$, texture of 12.6 $\mathrm{N}$, cooking loss of $16.7 \%, W H C$ of $32.9 \%$, sensory score more than 7 and electricity operating costs was $2,700 \mathrm{IDR} / 100 \mathrm{~kg}$ of dough.
\end{abstract}

KEYWORDS: bowl cutter, blade, fish nuggets, design

\section{PENDAHULUAN}

Upaya untuk meningkatkan nilai tambah dan mengoptimalkan pemanfaatan produksi perikanan tangkap adalah pengembangan produk bernilai tambah (Murniyati, Peranginangin \& Nurhayati 2012). Beberapa produk yang telah dikembangkan menggunakan bahan baku ikan di antaranya bakso, otak-otak, sosis dan nugget ikan. Selain meningkatkan nilai tambah, produk olahan ikan tersebut sejalan dengan kebutuhan masyarakat yang menuntut makanan cepat saji serta mengandung cukup gizi. Jadwal yang padat dan gaya hidup masyarakat yang sibuk menuntut seseorang untuk dapat makan dengan cepat. Selain cepat, kebutuhan makanan cepat saji 
juga harus memenuhi standar gizi dan kesehatan (Sudirdjo, 2013). Salah satu makanan cepat saji dari pengolahan produk perikanan adalah nugget ikan. Nugget ikan adalah produk olahan hasil perikanan yang menggunakan lumatan daging ikan dan atau surimi minimum $30 \%$ dicampur tepung dan bahan lainnya, dibaluri dengan tepung pengikat, dimasukkan ke dalam adonan butter mix kemudian dilapisi dengan tepung roti dan dipanaskan (BSN, 2013).

Proses pembuatan nugget ikan dilakukan dengan menggiling daging ikan kemudian mencampur dengan bahan lainnya seperti tepung dan bumbu sampai dihasilkan adonan yang homogen. Setelah homogen adonan dicetak kemudian dikukus selama kurang lebih 10 menit. Setelah itu dilapisi dengan larutan buttermix dan breadcrumbs kemudian digoreng (Murniyati et al., 2012). Proses pembuatan nugget ikan skala UKM dilakukan secara manual dan menggunakan peralatan sederhana. Peralatan yang diperlukan dalam proses pembuatan nugget ikan di antaranya mesin penggiling daging, mesin pengadon dan alat pengukus. Mesin pengadon untuk pembuatan nugget yang biasa digunakan adalah bowl cutter.

Bowl cutter yang ada di pasaran dapat digunakan untuk mencincang daging dan sayuran serta dapat pula digunakan untuk membuat adonan bakso, sosis maupun nugget. Komponen utama bowl cutter adalah pisau dan motor penggerak. Pisau berfungsi untuk mencacah daging sedangkan motor penggerak berfungsi untuk menggerakkan mangkuk dan pisau secara bersamaan. Bentuk pisau yang biasa digunakan dalam bowl cutter yang ada dipasaran umumnya berbentuk melengkung seperti ditunjukkan pada Gambar 1, dengan jumlah pisau bervariasi yaitu 2, 3 dan 6 buah. Bentuk dan jumlah pisau bowl cutter tersebut didisain umumnya untuk berbagai olahan dan berbagai jenis adonan. Bentuk dan jumlah pisau yang bervariasi tentunya akan menghasilkan mutu adonan dan konsumsi energi yang beragam. Penelitian terkait disain pisau dalam bowl cutter terutama untuk proses pembuatan adonan nugget ikan belum banyak dilakukan. Hal yang utama dalam penggunaan bowl cutter untuk pembuatan nugget skala UKM adalah biaya operasional yang rendah sehingga akan memberikan manfaat yang lebih besar. Oleh karena itu, disain dan jumlah pisau pada bowl cutter untuk pembuatan nugget ikan skala UKM perlu dipelajari agar diperoleh biaya operasional yang rendah dan menghasilkan nugget sesuai standar.

Penggunaan bowl cutterdalam pengolahan nugget ikan di beberapa UKM di Gunungkidul menunjukkan beberapa kendala di antaranya pencampuran adonan yang membutuhkan waktu relatif lama dan kualitas adonan yang kurang homogen. Jumlah dan bentuk pisau serta lamanya proses pengadonan yang dilakukan dalam pengolahan nugget ikan di beberapa UKM sangat bervariasi. Hal ini dapat mempengaruhi kualitas adonan nugget serta biaya operasional, sehingga diperlukan kajian mengenai bentuk dan jumlah pisau bowl cutter yang paling sesuai untuk pengolahan nugget ikan. Selain bentuk dan jumlah pisau, waktu pengadonan menjadi hal penting untuk diketahui. Bowl cutter yang biasa digunakan UKM menggunakan motor listrik dengan daya berkisar antara 1100 sampai 1900 Watt. Kebutuhan listrik tersebut cukup besar untuk skala UKM, sehingga pengadonan yang dilakukan sesingkat mungkin dengan mempertimbangkan kualitas nugget, dapat menghemat biaya operasional. Tujuan penelitian ini adalah menentukan desain pisau bowl cutter yang tepat serta menentukan lama pengadonan dalam proses pembuatan nugget ikan sehingga didapatkan kualitas nugget yang baik serta biaya operasional listrik yang rendah.

\section{BAHAN DAN METODE}

\section{Bahan}

Bahan yang digunakan untuk membuat pisau bowl cutter adalah plat stainless steel (SS) 304 tebal 2 $\mathrm{mm}$ dan batang teflon berdiameter $11 \mathrm{~cm}$. Peralatan

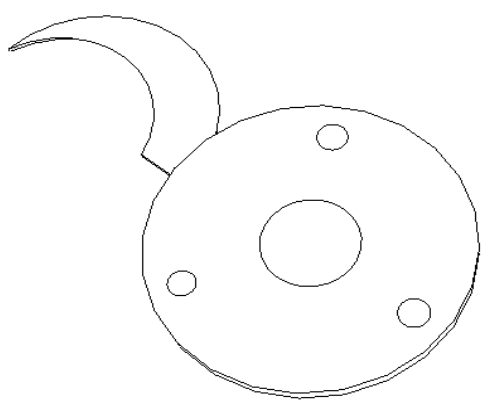

Gambar 1. Bentuk pisau bowl cutter di pasaran.

Figure 1. Shape of bowl cutter blade on the market. 
Tabel 1. Rancangan fungsional pisau.

Table 1. Functional design of blade.

\begin{tabular}{ll}
\hline \multicolumn{1}{c}{ Fungsi/Function } & \multicolumn{1}{c}{ Bagian Alat/Part } \\
\hline Memotong dan mengaduk adonan/Cutting and mixing the dough & Pisau/Blade \\
Menyalurkan torsi/Transmitting the torque & Poros penggerak/Driveshaft \\
Memegang pisau pada poros/Holding the blade on drive shaft & Dudukan/Blade Holder \\
Mengikat dudukan pada poros/Holding the blade holder on drive shaft & Baut/Bolt \\
Mengikat pisau pada dudukan/Holding the blade on the blade holder & Pin/Pins \\
Mengikat rangkaian pisau/Holding the sets of blade & Baut pengikat/Locking bolt \\
\hline
\end{tabular}

yang digunakan dalam pembuatan bilah pisau bowl cutter adalah mesin penekuk, mesin milling, gerinda dan mesin bubut. Peralatan yang digunakan dalam uji kinerja alat adalah bowl cutter dengan kapasitas volume bow/ sebesar $10 \mathrm{~L}$ dengan spesifikasi mesin $1700 \mathrm{~W}$ dengan komponen utama adalah motor listrik, pupy, belt, poros dan bowl. Peralatan lain yang digunakan dalam kegiatan uji kinerja adalah dandang, kompor, nampan, tang ampere serta stopwatch. Bahan yang digunakan dalam uji kinerja pembuatan nugget ikan adalah ikan patin, tepung terigu, tepung tapioka, tepung maizena, susu bubuk full cream, telur, garam, gula, lesitin dan bumbu. Uji kinerja dilakukan di Loka Penelitian dan Pengembangan Mekanisasi Pengolahan Hasil Perikanan, Bantul, Yogyakarta.

\section{Metode}

\section{Kriteria Disain}

Pisau dirancang untuk membantu proses pengadukan adonan yang terdiri dari campuran tepung, daging ikan dan bumbu-bumbu, sehingga menghasilkan adonan yang homogen serta kualitas nugget ikan sesuai standar SNI 7758.2013 (BSN, 2013) tentang nugget ikan. Parameter mutu nugget yang digunakan sebagai kriteria disain di antaranya nilai uji sensori di atas 7 dan kadar air maksimal $60 \%$. Kriteria disain pisau pengadon bowl cutterlainya adalah dapat digunakan pada bowl cutter yang menghasilkan adonan nugget dengan kapasitas sampai $6,6 \mathrm{~kg} /$ proses serta menggunakan material food grade.

\section{Rancangan Fungsional}

Fungsi utama dari bowl cutteradalah melumatkan daging ikan serta mengaduk campuran adonan untuk menghasilkan adonan nugget ikan yang homogen. Untuk mendukung fungsi utama tersebut dirancang sub-fungsi pendukungnya seperti disajikan pada Tabel 1. Berdasarkan sub-fungsi tersebut dipilih komponen atau bagian yang sesuai dengan sub-fungsinya.

\section{Rancangan Struktural}

Desain pisau dibuat dalam tiga bentuk yaitu tiga buah pisau lurus, tiga buah pisau melengkung dan enam buah pisau melengkung. Rancangan bentuk pisau tersebut berdasarkan pengamatan terhadap pisau pada bowl cutter dan peralatan dengan fungsi yang sama seperti pisau blander yang terdapat di pasaran. Ilustrasi desain pisau melengkung ditunjukkan pada Gambar 2, sedangkan disain pisau lurus ditunjukkan pada Gambar 3. Disain pisau

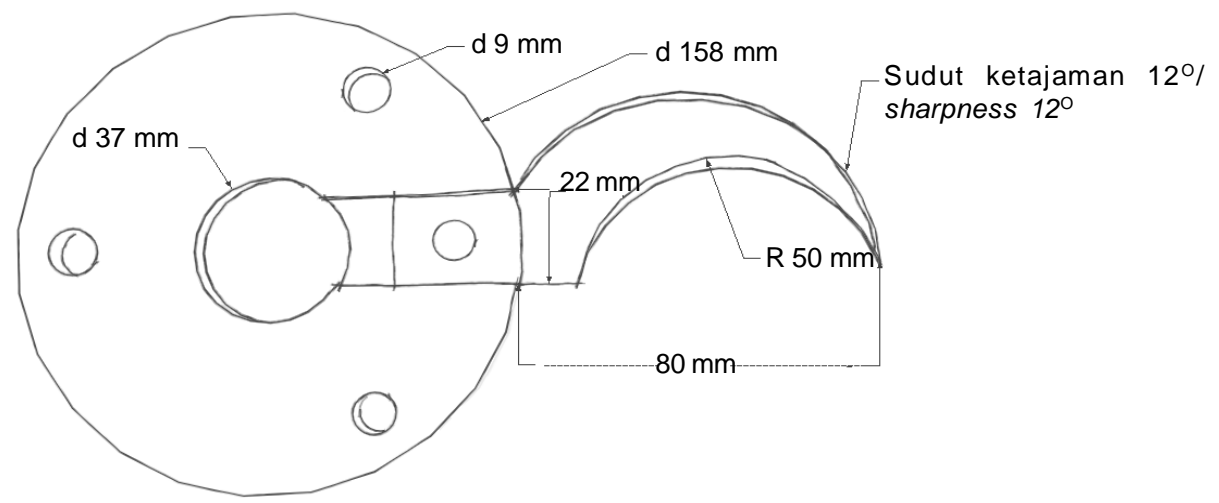

Gambar 2. Rancangan pisau melengkung.

Figure 2. Design of curve blade. 


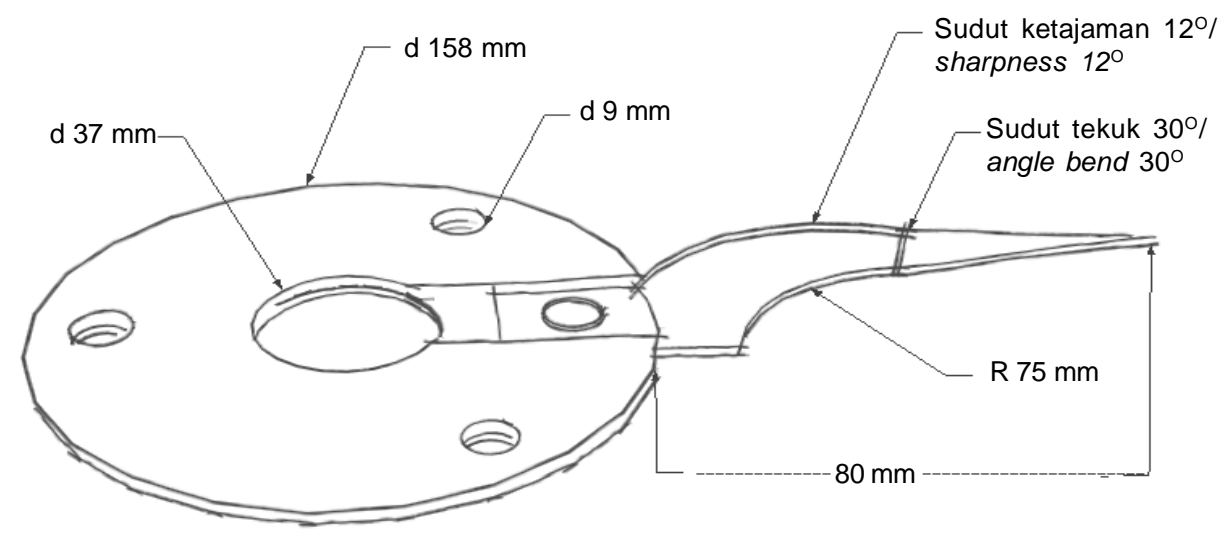

Gambar 3. Rancangan pisau lurus.

Figure 3. Design of straight blade.

melengkung mempunyai bentuk $\pm 3 / 8$ lingkaran (Gambar 2) dengan panjang $80 \mathrm{~mm}$ dari sisi luar dudukan. Lebar pisau sebesar $22 \mathrm{~mm}$ dengan tebal $3 \mathrm{~mm}$. Radius putar pisau dari pusat poros sebesar $130 \mathrm{~mm}$. Kelengkungan pisau mempunyai radius 50 $\mathrm{mm}$ dengan sisi tajamnya terletak pada lengkung bagian luar. Sudut ketajaman sekitar $12^{\circ}$ pada salah satu sisi pisau.

Disain pisau lurus (Gambar 3) mempunyai spesifikasi dan dimensi sama dengan disain melengkung kecuali pada radius kelengkungan sebesar $75 \mathrm{~mm}$ serta ujung pisau dibengkokkan dengan sudut $30^{\circ}$ dengan jarak yang dibengkok 25 $\mathrm{mm}$ dari ujung pisau. Material pisau terbuat dari plat SS 304, sedangkan dudukan pisau menggunakan bahan teflon. Teflon digunakan karena mudah dibentuk, keras dan aman untuk makanan. Pisau dipasang pada dudukan dengan menambahkan pin pengikat. Dudukan dibuat dengan bentuk cincin dengan diameter luar $158 \mathrm{~mm}$ dan diameter lubang bagian dalam $37 \mathrm{~mm}$ dengan tebal $10 \mathrm{~mm}$. Lubang bagian dalam digunakan untuk memasukkan poros penggerak. Tiap pisau diletakkan pada dudukan masing-masing secara terpisah. Tiap dudukan terdapat 3 buah lubang kecil dengan diameter $9 \mathrm{~mm}$ yang digunakan untuk baut pengikat, sehingga rangkaian pisau dapat terikat sempurna dalam poros.

Pisau dirangkaikan pada poros penggerak dengan memasukkan tiap dudukan pisau ke dalam poros penggerak kemudian diikat menggunakan baut seperti ditunjukkan pada Gambar 4. Susunan 3 dan 6 buah pisau pada rangkain dudukan diilustrasi pada Gambar 5. Jarak antar susunan pisau sebesar $10 \mathrm{~cm}$ dengan sudut putar antar pisau sebesar $120^{\circ}$ untuk rangkaian 3 pisau dan $60^{\circ}$ untuk rangkaian 6 pisau. Disain pisau yang dihasilkan kemudian dirangkaikan pada bowl

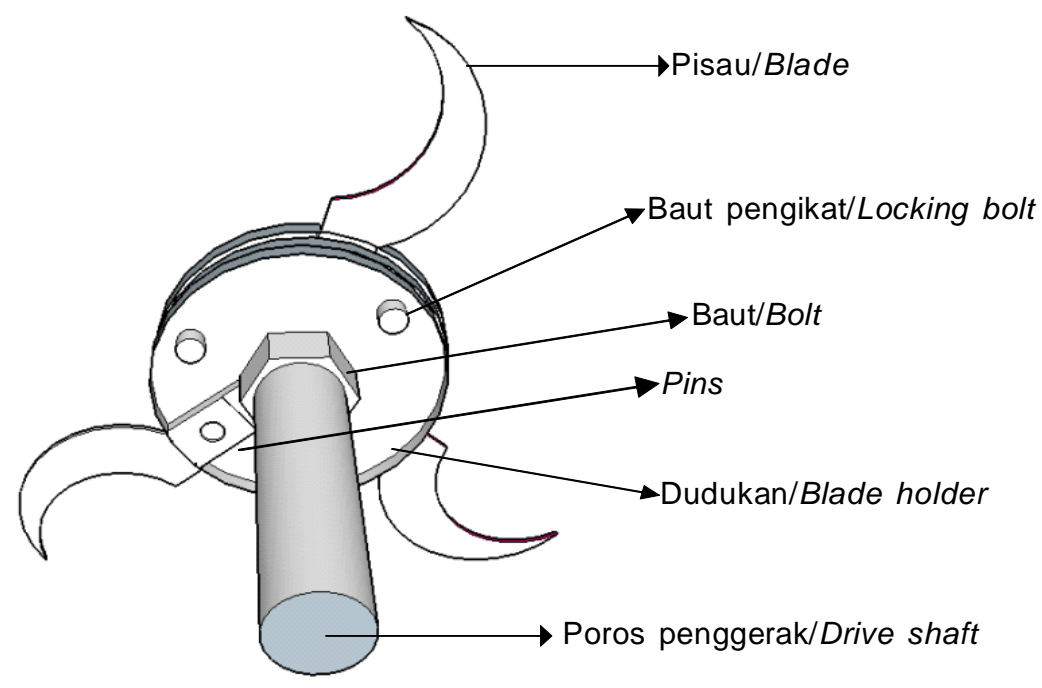

Gambar 4. Bagian pisau dalam poros penggerak

Figure 4. Part of blade on driveshaft 


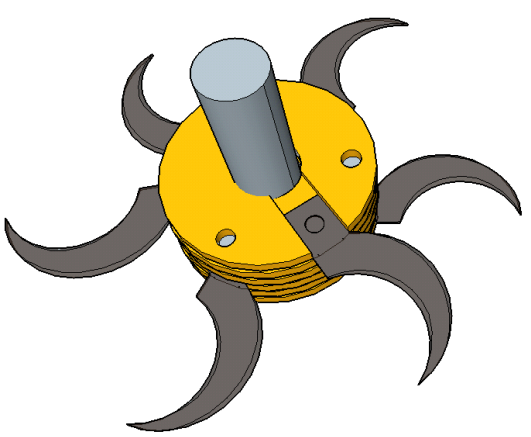

(a)

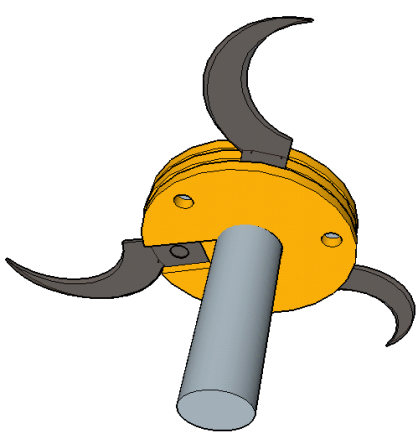

(b)

Gambar 5. Set 6 buah pisau (a) dan 3 buah pisau (b). Figure 5. Sets of 6 blades (a) and 3 blades (b).

cutter seperti ditunjukkan pada Gambar 6. Poros yang telah terangkai pisau digerakkan oleh motor pengerak melalui puly dan belt yang secara bersamaan berputar dengan bowl dengan kecepatan yang berbeda. Kecepatan putar pisau dan bow/ berturutturut sebesar 1535 dan $29 \mathrm{rpm}$.

\section{Uji Kinerja Alat}

Uji kinerja pisau pada bowl cutter dilakukan untuk mengetahui disain pisau terbaik pada variasi lama pengadonan selama 8, 12, dan 16 menit. Parameter pengujian adalah kualitas nugget dan biaya produksi yang dibutuhkan. Uji kinerja dilakukan dengan membuat nugget ikan menggunakan pisau dengan tahapan pembuat nugget seperti ditunjukkan pada Gambar 7. Disain pisau tersebut digunakan untuk membuat adonan nugget dengan waktu pengadonan masing-masing selama 8,12 , dan 16 menit, sehingga total perlakuan sebanyak sembilan dengan tiap perlakuan dilakukan dua kali ulangan. Kecepatan putar pisau dan bow/menjadi parameter tetap yaitu pada kecepatan masing-masing 1535 dan 29 rpm. Komposisi bahan pembuat nugget menggunakan formulasi yang dikembangkan Peranginangin dan Muljanah (2010) dengan modifikasi seperti ditunjukkan pada Tabel 2. Pada pembuatan nugget untuk tiap kali perlakuan digunakan sebanyak $5 \mathrm{~kg}$ fillet ikan patin (5 kali resep).

Kebutuhan listrik diketahui dengan mengukur arus listrik bowl cutter selama pengujian tiap menit menggunakan tang ampere digital. Parameter mutu nugget meliputi uji sensori (BSN, 2013), kadar air secara gravimetri, tekstur menggunakan texture

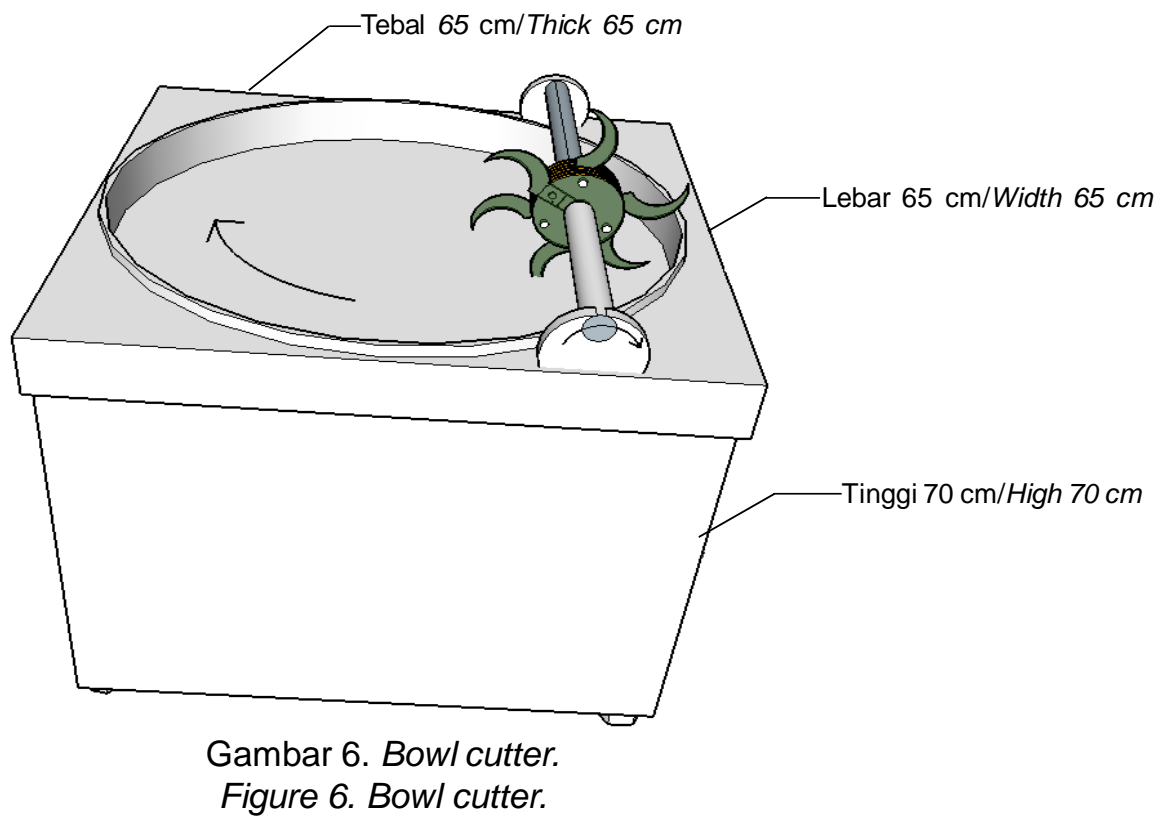




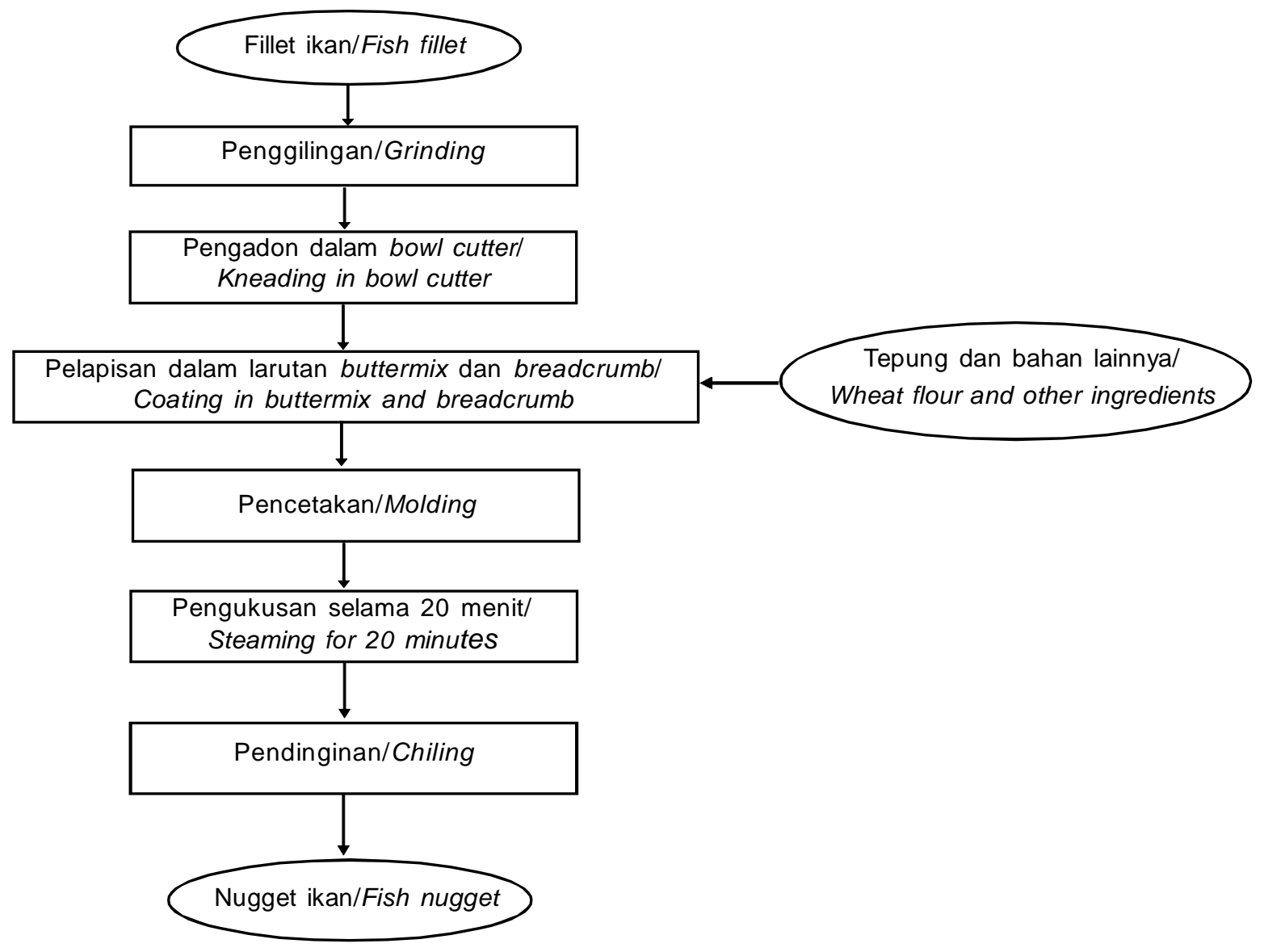

Gambar 7. Diagram alir pembuatan nugget

Figure 7. Flow chart of nugget processing

analyser, susut masak menggunakan metode Farida, Abustam dan Kadir (2012) dan Chuah, Normah, dan Yunus (1998) serta water holding capacity (WHC) menggunakan metode pengepresan oleh Pearson dan Dutson (1994). Disain pisau dan lama pengadonan yang terbaik ditentukan berdasarkan biaya operasional listrik terendah serta mutu nugget sesuai standar. Biaya operasional listrik pengadonan adalah perhitungan kebutuhan biaya listrik selama pengadonan.

Tabel 2. Bahan komposisi nugget

Table 2. Ingredient of fish nugget

\begin{tabular}{lc}
\hline \multicolumn{1}{c}{ Bahan/Ingredient } & Jumlah/Amount \\
\hline Fillet ikan/Fish fillet & $1000 \mathrm{~g}$ \\
Telur/Egg & 5 \\
Tepung terigu/Wheat flour & $55 \mathrm{~g}$ \\
Bawang putih/Garlic & $5 \mathrm{~g}$ \\
Garam/Salt & $25 \mathrm{~g}$ \\
Merica/Pepper & $12.5 \mathrm{~g}$ \\
Gula halus/Fine sugar & $50 \mathrm{~g}$ \\
Minyak sayur/Vegetable oil & 2.5 sendok/table spoon \\
Susu bubuk/Full cream milk & $75 \mathrm{~g}$ \\
Bumbu/Spice & $90 \mathrm{~g}$ \\
Lesitin/Lecithin & 0.5 sendok/table spoon \\
\hline
\end{tabular}




\section{HASIL DAN BAHASAN}

Proses pengadonan pada uji kinerja pisau bowl cutter untuk membuat adonan nugget ditunjukkan pada Gambar 8. Hasil pengukuran kapasitas pengadonan menunjukkan bahwa semua disain pisau mampu bekerja baik pada beban adonan sebanyak $6,6 \mathrm{~kg} /$ proses. Hal ini terlihat dari hasil pengukuran kecepatan putar pisau dan bowlyang berputar konstan pada kecepatan 1535 dan 29 rpm. Kebutuhan arus listrik dan energi selama uji kinerja pisau bowl cutter pada berbagai perlakuan ditunjukkan pada Gambar 9 dan Gambar 10. Kebutuhan rata-rata arus listrik selama proses pengadonan berkisar antara $4,07 \pm 0,02$ sampai 4,22 $\pm 0,02 \mathrm{~A}$ pada tegangan 220 Volt. Jumlah pisau yang lebih banyak menyebabkan kebutuhan arus semakin besar, sehingga kebutuhan daya pengadonan juga semakin besar. Pada disain yang sama, jumlah pisau yang semakin banyak menyebabkan gaya gesek yang terjadi antara permukaan pisau dengan adonan semakin besar, sehingga beban putar poros juga semakin besar yang

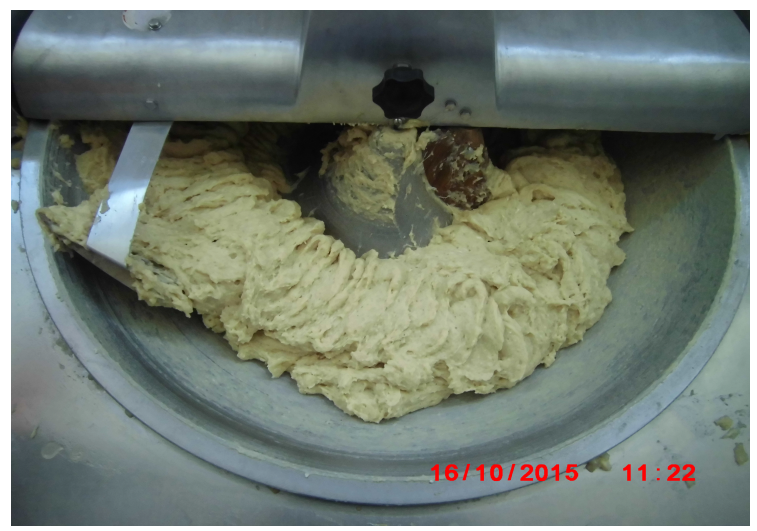

Gambar 8. Uji kinerja bowl cutter.

Figure 8. Performance test of bowl cutter.

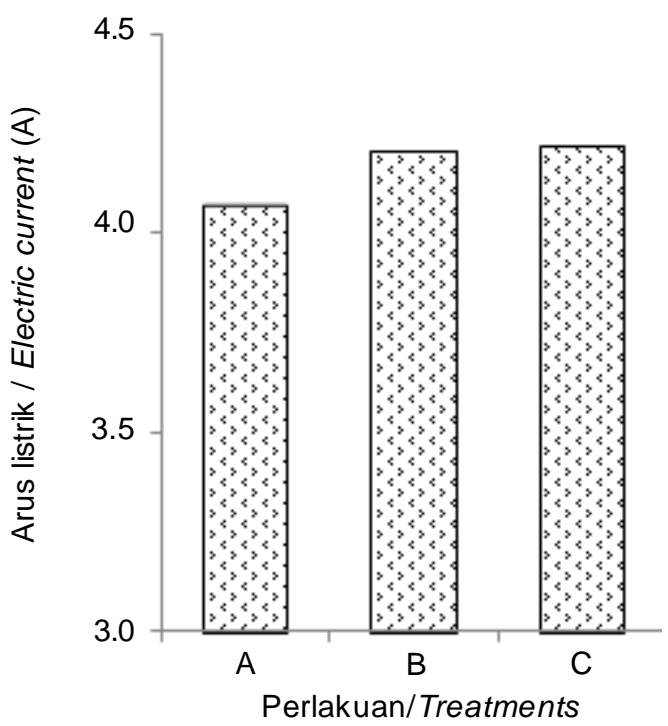

Keterangan/Note:

A : 3 pisau lengkung/3 curve blades

B : 6 pisau lengkung/ 6 curve blades

C : 3 pisau lurus/3 straight blades

Gambar 9. Kebutuhan arus listrik bowl cutter pada berbagai perlakuan.

Figure 9. Electric current consumption of bowl cutter on various treatments. 


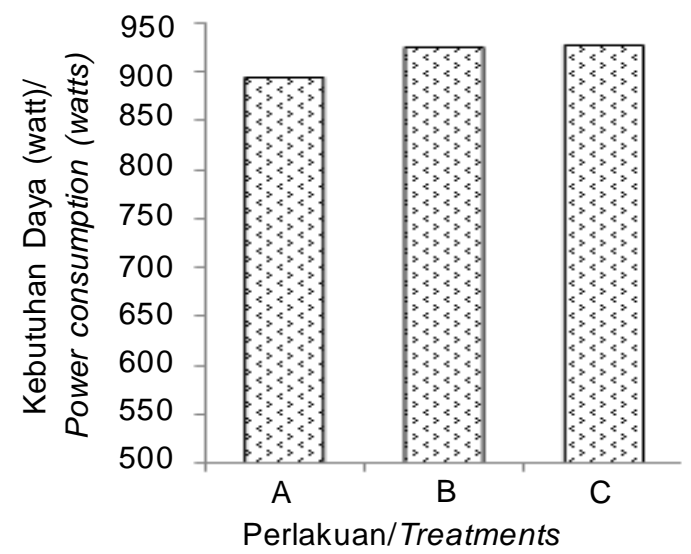

Keterangan/Note :

A : 3 pisau lengkung/3 curve blades

B : 6 pisau lengkung/ 6 curve blades

C : 3 pisau lurus/3 straight blades

Gambar 10. Kebutuhan daya bowl cutter pada berbagai perlakuan

Figure 10. Power consumption of bowl cutter on various treatments

mengakibatkan kebutuhan arus listrik juga bertambah. Pada jumlah pisau yang sama, disain pisau yang lurus dengan ujung yang dibengkokkan membutuhkan arus listrik dan energi yang lebih tinggi jika dibandingkan dengan disain pisau melengkung. Disain pisau melengkung menghasilkan sudut pemotongan antara sisi mata pisau dengan adonan lebih rendah sehingga tahanan pemotongan lebih rendah, sehingga disain pisau melengkung membutuhkan arus listrik yang lebih kecil dibandingkan dengan disain lurus. Kebutuhan arus listrik pisau disain melengkung ( 6 buah) nilainya hampir sama dengan disain lurus (3 buah) sebesar

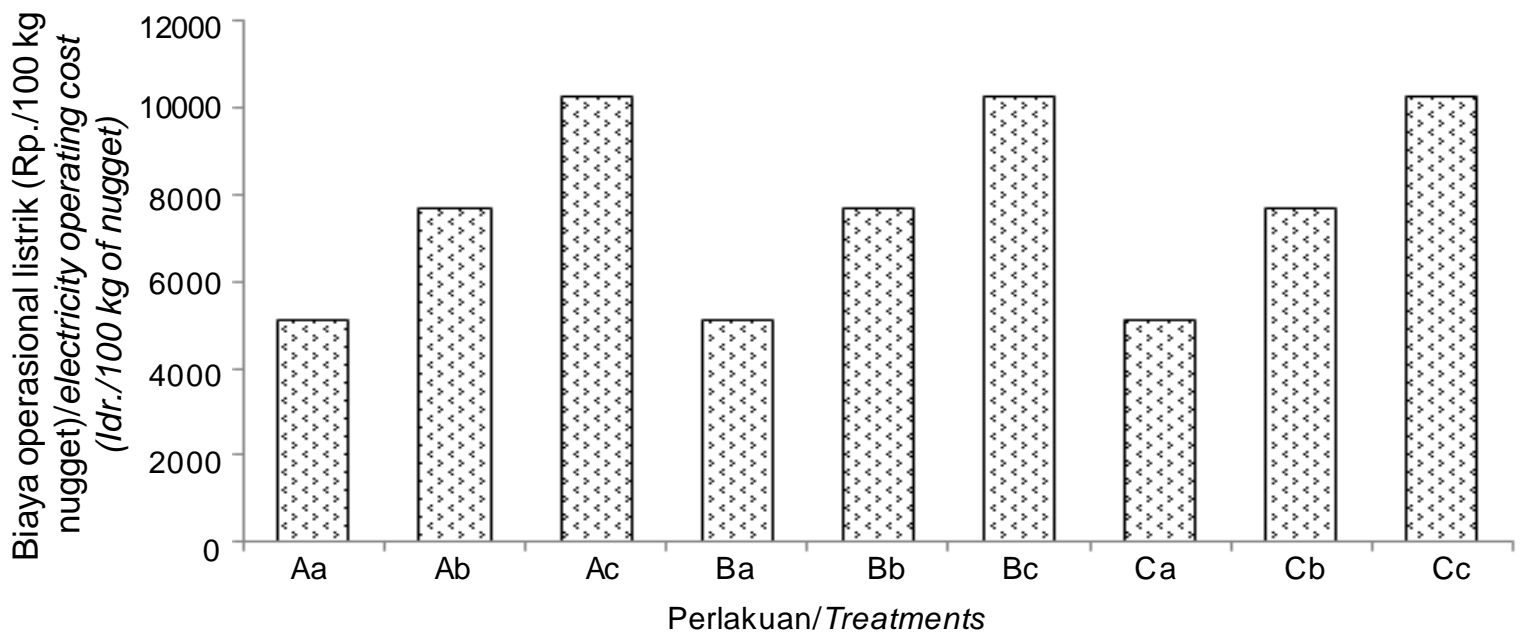

Keterangan/Note :

$\mathrm{Aa}: 3$ pisau lengkung, 8 menit/3 curve blades, $8 \mathrm{~min}$

$\mathrm{Ab}: 3$ pisau lengkung, 12 menit/3 curve blades, $12 \mathrm{~min}$

Ac : 3 pisau lengkung, 16 menit/3 curve blades, $16 \mathrm{~min}$

$\mathrm{Ba}: 6$ pisau lengkung, 8 menit/ 6 curve blades, $8 \mathrm{~min}$

$\mathrm{Bb}: 6$ pisau lengkung, 12 menit/ 6 curve blades, $12 \mathrm{~min}$

$\mathrm{Bc}: 6$ pisau lengkung, $16 \mathrm{menit} / 6$ curve blades, $16 \mathrm{~min}$

$\mathrm{Ca}: 3$ pisau lurus, $8 \mathrm{menit} / 3$ straight blades, $8 \mathrm{~min}$

$\mathrm{Cb}: 3$ pisau lurus, 12 menit/3 straight blades, $12 \mathrm{~min}$

Cc : 3 pisau lurus, 16 menit/3 straight blades, 16 min

Gambar 11. Biaya operasional listrik untuk pembuatan $100 \mathrm{~kg}$ nugget pada berbagai perlakuan

Figure 11. Electricity operating cost of $100 \mathrm{~kg}$ nugget processing on various treatments 
4,2 A. Kebutuhan daya selama pengadonan sebanding dengan arus yang dibutuhkan sebesar 895 - 928 Watt.

Hasil perhitungan kebutuhan biaya operasional listrik untuk pengadonan nugget tiap perlakuan ditunjukkan pada Gambar 11. Biaya operasional listrik pengadonan adalah perhitungan kebutuhan biaya listrik selama pengadonan yang nilainya berkisar antara Rp. 2.700,- sampai Rp. 5.400,- tiap $100 \mathrm{~kg}$ adonan dengan asumsi biaya listrik PLN sebesar Rp. $1.500,-/ \mathrm{kWh}$. Terlihat dalam Gambar 11 bahwa disain pisau terbaik adalah tiga pisau dengan lama pengadonan 8 menit dengan kebutuhan biaya listrik sebesar Rp. 2.700,- tiap $100 \mathrm{~kg}$ adonan.

Hasil pengujian organoleptik nugget pada berbagai perlakuan ditunjukkan pada Tabel 3. Secara umum hasil uji sensori nugget ikan pada berbagai perlakuan sesuai dengan standar SNI 7758.2013 (BSN, 2013), di mana nilai pengujian sensori untuk kenampakan, rasa, bau dan tekstur nugget ikan bernilai di atas 7 . Hal ini menunjukkan bahwa semua perlakuan menghasilkan nugget yang dapat diterima oleh panelis.

Kadar air nugget pada berbagai perlakuan menunjukkan nilai yang relatif sama yaitu berkisar antara 52,5-54,5\% seperti ditunjukkan pada Gambar 12. Kadar air tersebut sesuai standar SNI 7758.2013 (BSN, 2013).

Tabel 3. Karakteristik organoleptik nugget ikan Table 3. Sensory characteristics of fish nugget
Hasil pengukuran tekstur nugget pada uji kinerja bowl cutter pada berbagai perlakuan pisau berkisar antara 11,8-16,1 N seperti ditunjukkan pada Gambar 13 , sedangkan tekstur nugget komersial berkisar antara 10,8-33,5 N. Pada jumlah pisau yang sama, semakin lama proses pengadonan menghasilkan nugget dengan tekstur yang semakin kompak/padat. Pengadonan dan pencacahan yang semakin lama menyebabkan protein myofibril dapat terekstrak lebih banyak. Hal ini yang menyebabkan tekstur nugget semakin kompak (Lukman, Huda \& Ismail, 2009). Selain proses pengadukan, komposisi dan perlakuan penggorengan nugget juga berpengaruh terhadap tekstur nugget seperti dilaporkan oleh Chen, Chen, Chao dan Lin (2009). Menurut Evanuarini dan Purnomo (2011), semakin tinggi suhu penggorengan dan lama penggorengan akan menghasilkan nugget dengan kekerasan yang semakin tinggi.

Pengujian kadar water holding capacity (WHC) pada uji kinerja pisau bowl cutter pada berbagai perlakuan diperoleh nilai antara $22,9-35,5 \%$. Hasil pengujian WHC pada berbagai perlakuan ditunjukkan pada Gambar 14. Perlakuan bentuk dan jumlah pisau serta lamanya pengadonan tidak memberikan hasil yang linier dan cenderung beragam. Kadar WHC produk lebih disebabkan oleh faktor komposisi penyusun produk itu sendiri. Pada pembuatan nugget

\section{Skor/Score}

\begin{tabular}{lcccc}
\hline Perlakuan/Treatments Kenampakan/Appearance & Bau/Odour & Rasa/Taste & Tekstur/Texture \\
\hline $\mathrm{Aa}$ & 7.82 & 8.00 & 7.91 & 7.23 \\
$\mathrm{Ab}$ & 7.09 & 7.95 & 7.50 & 8.05 \\
$\mathrm{Ac}$ & 7.73 & 8.00 & 7.45 & 7.55 \\
$\mathrm{Ba}$ & 7.55 & 7.86 & 6.68 & 7.73 \\
$\mathrm{Bb}$ & 7.41 & 7.86 & 7.55 & 7.14 \\
$\mathrm{Bc}$ & 7.05 & 7.68 & 7.55 & 7.64 \\
$\mathrm{Ca}$ & 8.65 & 8.18 & 8.12 & 7.76 \\
$\mathrm{Cb}$ & 8.35 & 7.88 & 7.65 & 7.76 \\
$\mathrm{Cc}$ & 7.82 & 7.65 & 7.59 & 8.00 \\
Kontrol/Control & 8.00 & 7.09 & 7.18 & 6.91 \\
\hline
\end{tabular}

Keterangan/Note :

$\mathrm{Aa}: 3$ pisau lengkung, 8 menit/3 curve blades, $8 \mathrm{~min}$ $\mathrm{Ab}: 3$ pisau lengkung, 12 menit/3 curve blades, $12 \mathrm{~min}$ Ac : 3 pisau lengkung, 16 menit/3 curve blades, $16 \mathrm{~min}$ $\mathrm{Ba}: 6$ pisau lengkung, 8 menit/ 6 curve blades, $8 \mathrm{~min}$ $\mathrm{Bb}: 6$ pisau lengkung, 12 menit/ 6 curve blades, $12 \mathrm{~min}$ $\mathrm{Bc}: 6$ pisau lengkung, 16 menit/ 6 curve blades, $16 \mathrm{~min}$ $\mathrm{Ca}: 3$ pisau lurus, 8 menit/3 straight blades, $8 \mathrm{~min}$ $\mathrm{Cb}: 3$ pisau lurus,12 menit/3 straight blades, $12 \mathrm{~min}$ Cc : 3 pisau lurus, 16 menit/3 straight blades, $16 \mathrm{~min}$ 


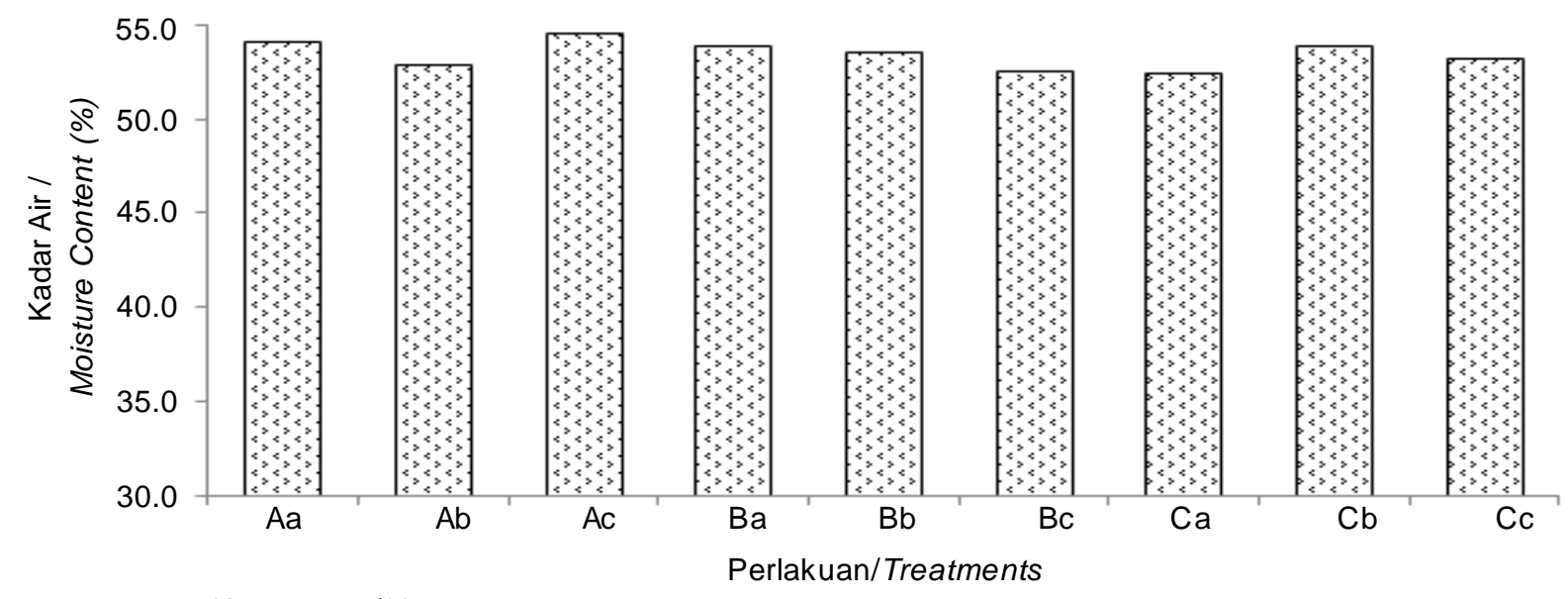

Keterangan/Note :

Aa: 3 pisau lengkung, 8 menit/3 curve blades, 8 min

$\mathrm{Ab}: 3$ pisau lengkung, 12 menit/3 curve blades, $12 \mathrm{~min}$

Ac: 3 pisau lengkung, 16 menit/3 curve blades, 16min

Ba: 6 pisau lengkung, 8 menit/ 6 curve blades, 8 min

$\mathrm{Bb}$ : 6 pisau lengkung, 12 menit/ 6 curve blades, $12 \mathrm{~min}$

Bc: 6 pisau lengkung, 16 menit/ 6 curve blades, 16 min

Ca: 3 pisau lurus, 8 menit/3 straight blades, $8 \mathrm{~min}$

$\mathrm{Cb}: 3$ pisau lurus, 12 menit/3 straight blades, $12 \mathrm{~min}$

Cc: 3 pisau lurus, 16 menit/3 straight blades, $16 \mathrm{~min}$

Gambar 12. Kadar air nugget pada berbagai perlakuan.

Figure 12. Moisture content of nugget on various treatments.

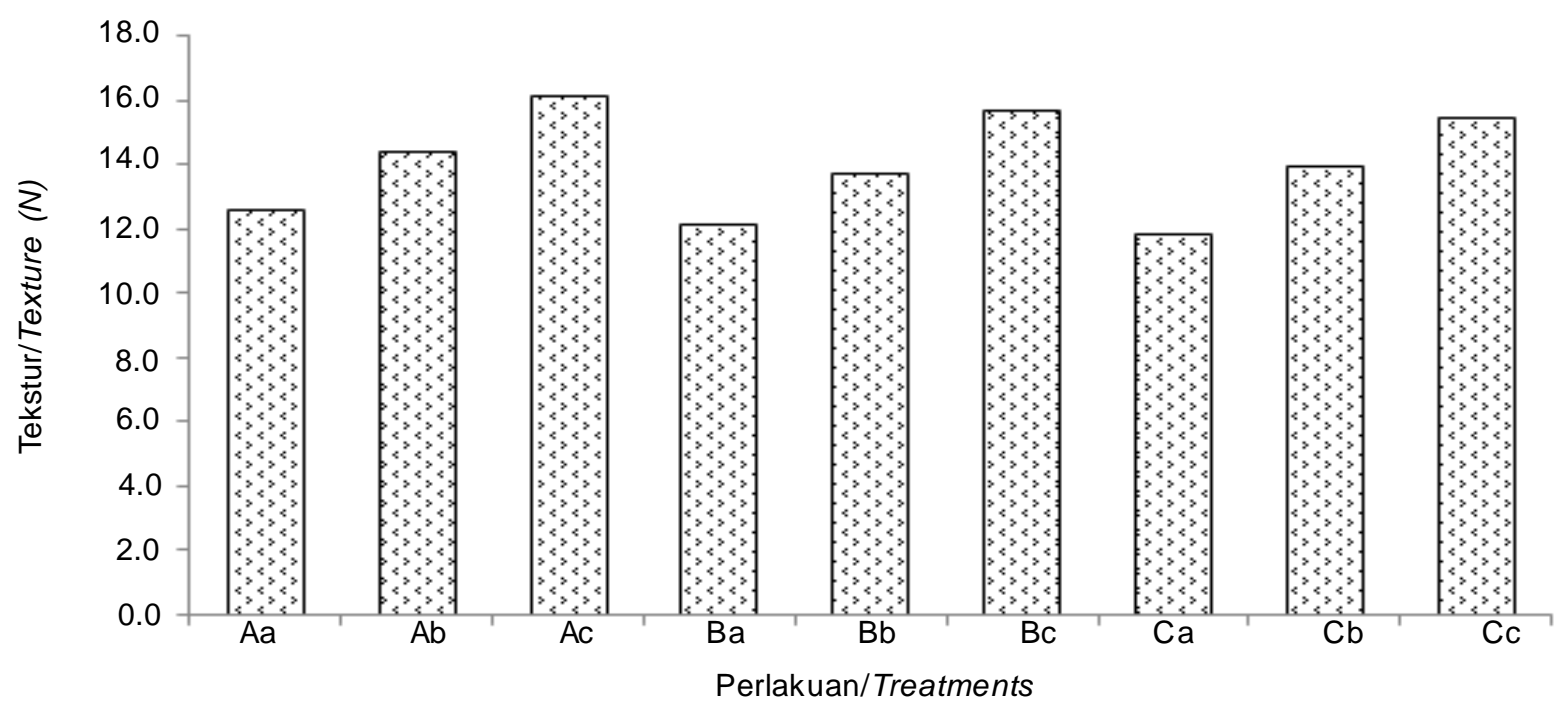

Keterangan/Note :

Aa: 3 pisau lengkung, 8 menit/3 curve blades, $8 \mathrm{~min}$

$\mathrm{Ab}: 3$ pisau lengkung, 12 menit/3 curve blades, $12 \mathrm{~min}$

Ac: 3 pisau lengkung, 16 menit/3 curve blades, $16 \mathrm{~min}$

Ba: 6 pisau lengkung, 8 menit/ 6 curve blades, $8 \mathrm{~min}$

$\mathrm{Bb}$ : 6 pisau lengkung, 12 menit/ 6 curve blades, $12 \mathrm{~min}$

Bc: 6 pisau lengkung, 16 menit/ 6 curve blades, 16 min

Ca: 3 pisau lurus, 8 menit/3 straight blades, $8 \mathrm{~min}$

$\mathrm{Cb}: 3$ pisau lurus, 12 menit/3 straight blades, $12 \mathrm{~min}$

Cc: 3 pisau lurus, 16 menit/3 straight blades, $16 \mathrm{~min}$

Gambar 13. Nilai tekstur nugget pada berbagai perlakuan.

Figure 13. Texture value of nugget on various treatments. 


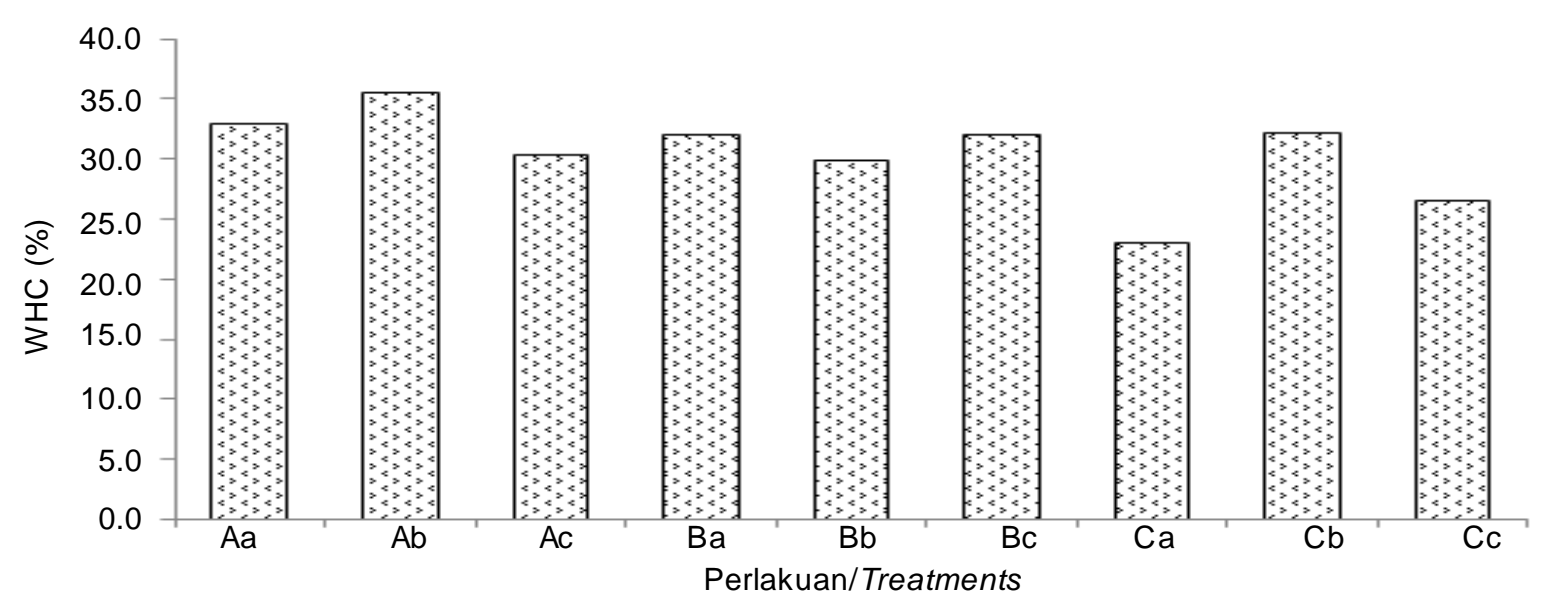

Keterangan/Note :

Aa: 3 pisau lengkung, 8 menit/3 curve blades, 8 min

$\mathrm{Ab}$ : 3 pisau lengkung, 12 menit/3 curve blades, $12 \mathrm{~min}$

Ac: 3 pisau lengkung, 16 menit/3 curve blades, $16 \mathrm{~min}$

Ba: 6 pisau lengkung, 8 menit/ 6 curve blades, $8 \mathrm{~min}$

$\mathrm{Bb}: 6$ pisau lengkung, 12 menit/ 6 curve blades, $12 \mathrm{~min}$

Bc: 6 pisau lengkung, 16 menit/ 6 curve blades, 16 min

Ca: 3 pisau lurus, 8 menit/3 straight blades, $8 \mathrm{~min}$

$\mathrm{Cb}: 3$ pisau lurus, 12 menit/3 straight blades, $12 \mathrm{~min}$

Cc: 3 pisau lurus, 16 menit/3 straight blades, $16 \mathrm{~min}$

Gambar 14. Nilai WHC nugget pada berbagai perlakuan.

Figure 14. WHC value of nugget on various treatments.

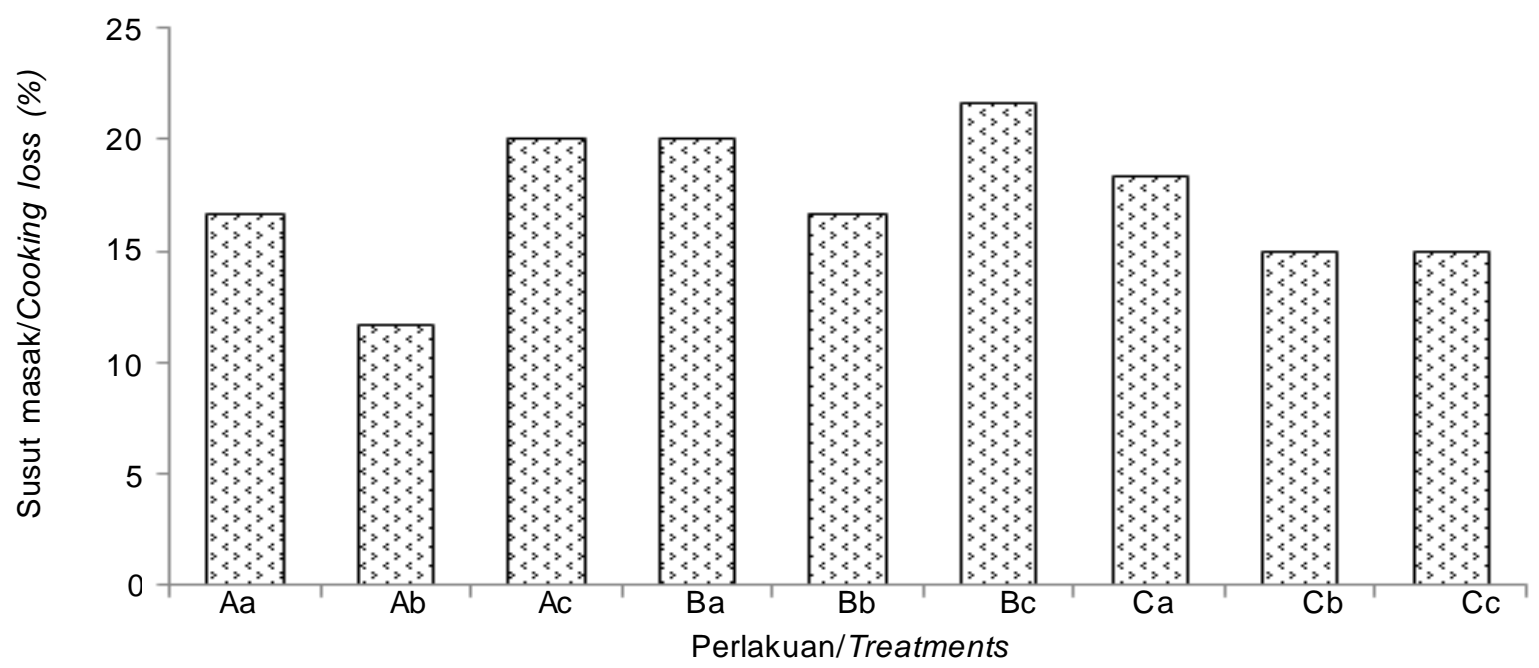

Keterangan/Note :

$\mathrm{Aa}: 3$ pisau lengkung, 8 menit/3 curve blades, $8 \mathrm{~min}$

$\mathrm{Ab}: 3$ pisau lengkung, 12 menit/3 curve blades, $12 \mathrm{~min}$

Ac : 3 pisau lengkung, 16 menit/3 curve blades, $16 \mathrm{~min}$

$\mathrm{Ba}: 6$ pisau lengkung, 8 menit/ 6 curve blades, $8 \mathrm{~min}$

$\mathrm{Bb}: 6$ pisau lengkung, 12 menit/ 6 curve blades, $12 \mathrm{~min}$

$\mathrm{Bc}: 6$ pisau lengkung, 16 menit/ 6 curve blades, $16 \mathrm{~min}$

$\mathrm{Ca}: 3$ pisau lurus, 8 menit/3 straight blades, $8 \mathrm{~min}$

$\mathrm{Cb}: 3$ pisau lurus, 12 menit/3 straight blades, $12 \mathrm{~min}$

Cc : 3 pisau lurus,16 menit/3 straight blades, $16 \mathrm{~min}$

Gambar 15. Persentase susut masak nugget pada berbagai perlakuan.

Figure 15. Cooking loss percentage of nugget on various treatments. 
ayam dengan komposisi tepung beras yang berbedabeda menunjukkan perbedaan nilai WHC produk yang dihasilkan (Maliluan, Pramono dan Dwiloka, 2014). Salah satu faktor yang mempengaruhi kadar WHC adalah faktor genetik daging yang menentukan kemampuan terikatnya air dalam struktur otot dan dalam sel otot (Lonergan \& Lonergan, 2005). Selain itu daya ikat air berkaitan dengan kemampuan protein otot dalam mengikat air, sedangkan kemampuan mengikat air protein otot dipengaruhi oleh nilai $\mathrm{pH}$ dan jumlah ATP jaringan (Suryaningsih, 2010).

Nilai susut masak pada uji kinerja pisau bowl cutter pada berbagai perlakuan berkisar antara 11,7$21,7 \%$ seperti ditunjukkan pada Gambar 15 . Susut masak menunjukkan persentase penurunan bobot yang terjadi selama pemasakan. Salah satu yang dapat dilakukan untuk mengurangi susut masak pada produk nugget ayam di antaranya dengan menambahkan bahan pengisi filler dengan menggunakan tepung tapioka atau tepung sagu (Komansilan, 2015). Penelitian lain oleh Tricahyo, Widati dan Widyastuti (2012), menunjukan bahwa penambahan rumput laut pada nugget kelinci dapat menurunkan susut masak, meningkatkan $\mathrm{pH}, \mathrm{WHC}$ dan keempukan.

Berdasarkan hasil pengukuran mutu nugget terlihat bahwa semua perlakuan menghasilkan mutu nugget yang sesuai standar. Pertimbangan utama yang digunakan dalam penentuan disain mata pisau terbaik adalah biaya operasional listrik selama pengadonan, di mana parameter tersebut sangat penting dalam penerapan bowl cutter pada usaha pembuatan nugget skala UKM. Hasil uji kinerja menunjukkan bahwa disain pisau bowl cutter terbaik terdiri dari 3 buah pisau melengkung dengan lama pengadonan 8 menit. Pada perlakuan tersebut kebutuhan biaya operasional listrik terendah yaitu sebesar Rp. 2.700/100 kg, dengan mutu nugget sesuai standar.

\section{KESIMPULAN}

Hasil penelitian menunjukkan bahwa disain bowl cutter terbaik terdiri dari 3 buah pisau melengkung dengan lama pengadonan 8 menit. Nugget yang dihasilkan pada kondisi tersebut mempunyai kadar air $54,2 \%$, tektur $12,6 \mathrm{~N}$, susut masak $16,7 \%$, WHC $32,9 \%$, nilai organoleptik lebih dari 7 dan biaya operasional listrik sebesar Rp. 2.700,-/100 kg adonan.

\section{DAFTAR PUSTAKA}

[BSN] Badan Standardisasi Nasional. (2013). Nugget Ikan. SNI 7758.2013. Badan Standardisasi Nasional. Jakarta.

Chuah, E.C., Normah, O., \& Yunus, J.M. (1998). Development of low-fat chicken nuggets. Tropical Agricultural and Food Scence Journal, 26(1), 93-98.
Chen, S.D., Chen, H.H., Chao, Y.C., \& Lin, R.S. 2009. Effect of butter formula on qualities of deep-fat and microwave fried fish nuggets. Journal Of Food Engineering, 95, 359-364.

Evanuarini, H., \& Purnomo, H. (2011). Physical and organoleptic quality of chicken nuggets fried at different temperature and time. Journal of Agricultute and Food Technology, I(8), 133-136.

Farida, Abustam, E., \& Kadir, S. (2012). Kualitas bakso kelinci pada kondisi rigormortis yang berbeda dengan penambahan tepung kanji dan tepung sagu. Jurnal Sains dan Teknologi, 12(1), 277-286.

Pearson, A.M., \& Dutson T.R.,(Eds). (1994). Quality attributes and their measurement in meat, poultry and fish products. Inggris : Blackie Academic \& Professional. 139-142.

Komansilan, S. (2015). Pengaruh penggunaan beberapa jenis filler terhadap sifat fisik chicken nugget ayam petelur afkir. Jurnal Zootek, 35(1), 106116.

Lonergan, E.H., \& Lonergan, E.M. (2005). Mechanisms of water holding capacity of meat : the role of postmortem biochemical and structural changes. Meat Science, 771, 194-204.

Lukman, I., Huda, N., \& Ismail, N. (2009). Physicochemical and sensory of commercial chicken nuggets. Asian Journal of Agro-industry, 2(02), 171180.

Maliluan, C., Pramono, Y.B., \& Dwiloka, B. (2014). Physical and Sensory Characteristcs of Chicken Nuggets with Utilization Rice Bran to Substitute Wheat Flour. Journal of Applied Food Technology, 1 (1), 4-7.

Murniyati, Peranginangin, R., \& Nurhayati. (2012). Penambahan shredded surimi dan pengaruhnya pada mutu nugget ikan cakalang, katuwonis pelamis. Prosiding Seminar Nasional Tahunan IX Hasil Penelitian Perikanan dan Kelautan. Universitas Gadjah Mada, PA-05, 1-11.

Peranginangin, R. \& Muljanah, I. (2010). Teknologi pemanfaatan zero waste concept dari pengembangan produk berbasis ikan patin (Pangasius sp.). Prosiding Seminar Nasional Masyarakat Pengolahan Hasil Perikanan Indonesia, Universitas Padjadjaran, 145 - 155 p.

Sudirdjo, F. (2013). Kualitas kimia nugget ikan tenggiri dengan menggunakan tepung ubi jalar yang diformulasikan menggunakan komposisi kimia nugget komersial. Prosiding Seminar Nasional Tahunan X Hasil Penelitian Perikanan dan Kelautan. Universitas Gadjah Mada, PA-06, 1-4

Suryaningsih, L. (2010). Kajian berbagai metoda thawing terhadap keempukan, daya lkat air dan susut masak daging sapi bagian paha. Prosiding Seminar Nasional 2. Fakultas Peternakan Universitas Padjadjaran, 630-634.

Tricahyo, A., Widati, A.S., \& Widyastuti, E.S. (2012). Pengaruh penambahan filler komposit (wheat bran dan pollard) dan rumput laut terhadap $\mathrm{pH}, \mathrm{WHC}$, cooking loss dan tekstur nugget kelinci. Ternak Tropika, 13(1), 19-29. 